\title{
APPLICATION OF LEAN MANUFACTURING TO IMPROVE THE ELECTRONICS INDUSTRY IN EGYPT: A CASE STUDY
}

\begin{tabular}{|l|l|l|l|}
\hline $\begin{array}{l}\text { Ali Abd El-Aty*, } \\
\text { Department of Mechanical } \\
\text { Engineering, Helwan }\end{array}$ & $\begin{array}{l}\text { Ahmad Farooq } \\
\text { Department of Mechanical }\end{array}$ & $\begin{array}{l}\text { Azza Barakat*, } \\
\text { Department of Mechanical } \\
\text { Engineering, Nanjing }\end{array}$ & $\begin{array}{l}\text { Mohamed Etman } \\
\text { Department of Mechanical }\end{array}$ \\
$\begin{array}{l}\text { University, Cairo, Egypt. } \\
\text { abdelaty85@ gmail.com }\end{array}$ & $\begin{array}{l}\text { University of Aeronautics and } \\
\text { Astronautics, Nanjing, China } \\
\text { ahmf239@yahoo.com }\end{array}$ & $\begin{array}{l}\text { Eniversity, Cairo, Egypt. } \\
\text { abarakatazza5@ hotmail.com } \\
\text { barakatazza5@ } @ \text { hotmail.com }\end{array}$ & $\begin{array}{l}\text { University, Cairo, Egypt. } \\
\text { dretman@ gmail.com }\end{array}$ \\
\hline
\end{tabular}

* Corresponding authors

\begin{abstract}
The aims of this research is to apply, investigate the adoption of lean manufacturing in industrial systems especially the electronics industry and re-design this system according to the different concepts of lean manufacturing by elaborating a pull-oriented manufacturing system. This research was applied at the assembly line of Sunny Egypt Company for Electronics Industry which related to Union Air Group at Egypt. Cathode ray tube 14" model television was selected from the products of the company for improvement. The Results acquired from this research showed that the application of lean manufacturing in industrial systems increases productivity, profit, improves quality, eliminates wastes, decreases cycle times, work in progress, inventory, raw materials, costs and number of worker. This research can be useful in developing a more generic approach to design lean environment.
\end{abstract}

Keywords-lean manufacturing; pull manufacturing; push manufacturing; lead time; cycle time; work in progress.

\section{INTRODUCTION}

In recent years, it has become increasingly difficult to make more profit for manufacturing industry in western countries such as the US and the UK. On the other side of the world, the traditional manufacturing industry has moved to some rapidly developing countries like China, India and Egypt in search of cheap labour and more profit. The pressures to increase sales, reduce cost, increase salaries and introduce new products are all contributing factors that complicate the manufacturing management [1]. This is the harsh reality facing the manufacturing industry today. Manufacturers in the electronics industry have always faced heightened challenges such as rising customers' expectation, fluctuating demand, and competition in markets [2]. There is no doubt that these manufacturers are always embracing changes and improvements in their key activities or processes to cope with the challenges [3]. One way to stay competitive in this globalized market is to become more efficient. Lean manufacturing has been receiving a lot of attentions in the industry [4]. The effects claimed after implementing it are enormous. Lean manufacturing uses less of everything compared to mass production - half the human effort in the factory, half the manufacturing space, half the investment in tools, and half the engineering hours to develop a new product [5]. Lean manufacturing was successfully implemented in automotive industries, steel making industries, Aerospace industries, Machine tool industries, Newspapers industries, Service industries, Electrical and Electronics' industries [1, 2, $4,5,6]$.

\section{PROBLEM STATMENT}

The problems that the company was facing are just like all other companies in the traditional manufacturing industry, high lead time, high production cost, high work in progress, high number of raw materials in assembly line, high inventory and high delivery time. All the previous reasons push the upper management of the company to implement lean manufacturing in current production system. The authors and the company selected Cathode Ray Tube (CRT) 14" model for improvement. Steps of application lean manufacturing techniques in present system will be implemented according to the methodology explained in the next section.

\section{APPLICATION OF LEAN MANUFACTURING TOOLS ON THE PRESENT PRODUCTION SYSTEM}

\section{A. Construct the value stream mapping for the product}

This step is divided into two stages, the first stage is to construct value stream mapping (VSM) for the present production system and the second stage is to use this VSM to identify the different types of wastes in this system. To construct the VSM of the product, the following data must be obtained; Attributes of the assembly process as shown in Table 1, Information about material flow, Cycle times and number of operators per process for each process in assembly process, as shown in Table 2 and finally, Inventory between processes or work in progress (WIP). The authors used IGrafx Process 2007 for Enterprise Modeller software construct VSM, view time line and work balancing graph for present situation as shown in "Fig. 1,". As shown in "Fig. 2," an important summary box obtained from time line diagram that depicted in "Fig. 1,". It's detected from these figures that WIP between each process are not the same and very high, the total lead time is higher than the real lead time, the value added time is much smaller than the real than the real value added time and the number of raw materials in assembly line is much longer than required, which indicate that the assembly line of current production system was unbalance production system, as well as, overproduction and large inventory have found in the assembly line of current production system $[1,2]$.

The second stage of this step is detecting and eliminating the different types of wastes throughout the stream to shorten lead-time and increase the value-added time. According to the Toyota Production System, there are seven types of wastes that do not contribute to the value of the product: 


\section{(2) \\ ELK \\ Asia Pacific Journals}

overproduction, inventory, transportation, waiting, motion, over-processing, and defects. From the present VSM, all seven types of wastes are detected [2].

\section{B. Proceeding value stream flow without interruption}

According to different types of wastes which mentioned previously, Takt time analysis, Six S's, visual display \& control, were selected from lean manufacturing tools to implement in current system, since, these tools are the most tools compatible and effective for current production. Takt time is "Beat Time" or "Rate Time" $[1,3]$. That means the speed to control entire manufacturing system. In lean principles, Takt time is used as the rate or the time that a completed product is finished. Takt time is the number of units required by the customer per unit of time. "(1)," is used to calculate Takt time [2, 4]:

\section{Takt Time $=$ Available Time $/$ Customer Demand}

Takt time for this model was 75 second as shown in Table 3 ; this means that the company must produce this product 75 second to meet the customer's demand. In order to develop a current production system and convert it in to lean manufacturing system, cycle time must be reduced to become less than or equal Takt time [4]. Uncontrolled lost time during working day was observed. Hence, goal time was used instead of Takt time during implementing lean manufacturing and drawing future VSM to vanish the effects of uncontrolled lost time and access to one piece flow system [1,4]. Goal time is the percentage of takt time determined by authors and company as “(2)," [4,5].

\section{Goal Time $==93 \%$ of Takt Time}

Six S's were selected as the second lean manufacturing techniques to apply in present system while Visual display and control were selected as the third tool to implement. Six S's primary goal was to reduce waste and optimize productivity through maintaining an orderly workplace to achieve more consistent operational results. The S's of $6 \mathrm{~S}$ are originally Japanese words. Sort, Straighten, Shine, Systemize, Sustain and Safety have been frequently adopted as the English equivalent. The authors used Sort, Straighten, Shine, Systemize, Sustain and Safety to organize the workplace and getting rid of nonsense, clutter, wastes, materials, tools and dies that haven't used in the near future and leaving only the supplies, tools and materials necessary to perform daily works. Disposing of these unused items frees up workplace, reduces the number of obstacles to walk around and reduces the required time to find needed items. When "sorting" is well implemented, communication between operators is improved and product quality and productivity are increased [6].
ELK Asia Pacific Journals - Special Issue ISBN: 978-81-930411-4-7

\begin{tabular}{|l|r|}
\hline General Working Time & 8.5 hours / day \\
\hline Break Time & 1 hours / day \\
\hline Actual Working Time & 7.5 hours / day \\
\hline Number of Shift per day & 1 shift / day \\
\hline Number of Working Days per week & 5 days / week \\
\hline Required Quantities to be produced per week & 2250 units / week \\
\hline Required Quantities to be produced per day & 450 units / day \\
\hline Number of raw materials per day & 1000 parts / day \\
\hline Actual Quantities produced per day & 400 units / day \\
\hline Number of accepted products per day & 388 units / day \\
\hline Number of rejected products per day & 12 units / day \\
\hline
\end{tabular}

TABLE II. NUMBER OF OPERATIONS AND CYCLE TIMES FOR EACH PROCESS CRT 14" MODEL OF PRESENT SYSTEM

\begin{tabular}{|c|c|c|c|}
\hline $\begin{array}{l}\text { Number } \\
\text { of } \\
\text { process }\end{array}$ & Process name & $\begin{array}{l}\text { Number } \\
\text { of } \\
\text { operatos }\end{array}$ & $\begin{array}{c}\text { Cycle } \\
\text { Time }\end{array}$ \\
\hline 1 & Deg. And CRT Preparation. & 3 & 162 \\
\hline 2 & Cabinet Preparation & 1 & 71 \\
\hline 3 & CRT fixing & 1 & 67 \\
\hline 4 & D.Y.SOC.SOL & 1 & 62 \\
\hline 5 & Board Preparation & 1 & 85 \\
\hline 6 & Board fixing & 1 & 57 \\
\hline 7 & Cables tying and collecting & 1 & 45 \\
\hline 8 & Inspection of assembly & 1 & 60 \\
\hline 9 & Colour inspection & 1 & 45 \\
\hline 10 & Dimension inspection inspection & 1 & 51 \\
\hline 11 & Inspection of audio and video & 1 & 48 \\
\hline 12 & Internal inspection & 1 & 43 \\
\hline 13 & speaker Preparation & 1 & 45 \\
\hline 14 & Back Preparation & 3 & 214 \\
\hline 15 & Back Fixing. & 3 & 167 \\
\hline 16 & Life signal & 1 & 57 \\
\hline 17 & Shape inspection & 1 & 69 \\
\hline 18 & Acc. Preparation \&Numbering & 1 & 75 \\
\hline 19 & Carton Preparation & 1 & 27 \\
\hline 20 & Packaging & 2 & 106 \\
\hline
\end{tabular}

TABLE III. TAKT AND GOAL TIMES FOR CRT 14" MODEL

\begin{tabular}{|c|c|c|c|c|}
\hline Model & $\begin{array}{c}\text { Actual working time } \\
\text { (Sec.) }\end{array}$ & $\begin{array}{c}\text { Customer's } \\
\text { demand } \\
\text { (Unit / day) }\end{array}$ & $\begin{array}{c}\text { Takt } \\
\text { Time(Sec) }\end{array}$ & $\begin{array}{c}\text { Goal } \\
\text { Time } \\
\text { (Sec) }\end{array}$ \\
\hline CRT & 27000 & 360 & 75 & 69 \\
\hline
\end{tabular}

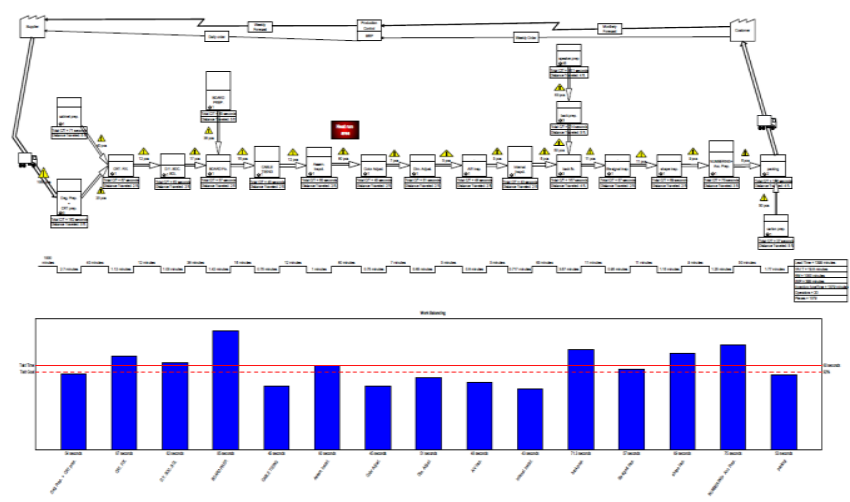

Fig. 1. Present value stream mapping of CRT 14" model 


\begin{tabular}{|l|}
\hline Lead Time $=1399$ minutes \\
\hline $\mathrm{VA} / \mathrm{T}=19.8$ minutes \\
\hline $\mathrm{RM}=1000$ minutes \\
\hline $\mathrm{WIP}=399$ minutes \\
\hline Inventory typeTime $=1379$ minutes \\
\hline Operators $=20$ \\
\hline Pieces $=1379$ \\
\hline
\end{tabular}

Fig. 2. Summary box of time line diagram for CRT 14" model

Visual display and control is a key method for making bold improvements is to make line failures or other factoryfloor problems visible and obvious enough so that anyone can easily spot them. Visual display and control is the important element of visual factory. Visual Display communicates important information but does not control what people or machines do. Displays help avoid confusion, mix-up and speeds up activity. Visual Controls communicate information so that activities are performed according to standards and help monitor and control. Visual display and control include many application methods, each suited to a different type of management problem. Some of these methods help to identify waste while others help to bring latent problems to the surface. Red tag strategy, Signboard strategy, White demarcation, Red demarcation, Andon and Defective item display were selected to implement in current system $[5,6]$.

\section{Transform the system from push manufacturing to pull manufacturing}

Some preparation processes have small cycle time if compared to other processes and the quantities which produced from these processes were very high if compared to the required quantities. . This was done by implementing pull production or Kanban production system for these preparation processes. Kanban production system are implemented as follows: (a) Calculate the required number of Kanban cards as shown in Table 4 (b) Design the signalling mechanism (c) Train the operators (d) Start the Kanban (e) Improve the Kanban. The required number of Kanban or Kanban cards was calculated based on the current needs of the organization, not on future plans. "(3)," was used to calculate number of required Kanban, where: $\mathrm{N}$ is the Number of Kanban cards or containers per day, $\mathrm{H}$ is the Highest daily demand, $\mathrm{S}$ is the daily Safety Stock which the percentage of highest daily demand and finally $\mathrm{C}$ is the Container size $[1,3]$.

$\mathrm{N}=(\mathrm{H}+\mathrm{S}) / \mathrm{C}$

\section{Line balance}

Line balance or production levelling was applied to plan and level customer demand by volume and variety, while keeping the level of production as constant over a specific time period. This step includes constructing a work balancing diagrams of the future states and then using these diagrams to exanimate the effects of these steps by eliminating wastes and reducing cycle times of each manufacturing process to be less than or equal to the Takt time. There are two stages which must be

\begin{tabular}{|c|c|c|c|c|c|c|}
\hline $\begin{array}{l}\text { Model } \\
\text { Name }\end{array}$ & $\begin{array}{l}\text { Process } \\
\text { Name }\end{array}$ & $\begin{array}{l}\text { Part } \\
\text { Name }\end{array}$ & $\begin{array}{c}\text { H } \\
\text { (Product } \\
\text { / day) }\end{array}$ & $\mathbf{S}$ & $\begin{array}{c}\mathrm{C} \\
\text { (Product/ } \\
\text { container) }\end{array}$ & $\begin{array}{c}\mathrm{N} \\
\text { (Card } \\
/ \text { day) }\end{array}$ \\
\hline \multirow[b]{2}{*}{$\begin{array}{l}\text { CRT } \\
14^{\prime \prime}\end{array}$} & $\begin{array}{c}\text { Speaker } \\
\text { preperation }\end{array}$ & Speaker & \multirow{2}{*}{450} & \multirow{2}{*}{$\begin{array}{c}\begin{array}{c}11 \% \\
\text { of } \\
450 \\
= \\
50\end{array}\end{array}$} & 50 & 10 \\
\hline & $\begin{array}{c}\text { Carton } \\
\text { preperation }\end{array}$ & Carton & & & 25 & 20 \\
\hline
\end{tabular}

TABLE IV. TAKT NUMBER OF KANBAN CARDS FOR PREPARATION PROCESSES OF CRT 14" MODEL

followed to accomplish and implement production levelling in its current production system: (a) view the time line diagram and work balancing graph to show the cycle time of each process in assembly process, required Takt time to produce required quantity and (b) balance the assembly process by distributing operator work elements in relation to Takt time.

\section{E. Standardization}

Standard operations are the final and important step in applying lean manufacturing and eliminating the wastes. It refers to organizing the job and performing it in the most effective way after levelling by writing each of the process sequences for the assembly, since it does not depend on the presence or absence of operators. The operation also includes minimizing cycle times, overproduction, WIP, waiting, motion and over processing. . Work instructions of each process in assembly process for CRT 14" model were done and accomplished. The team followed the sequences of work instructions of Toyota production system (TPS), where, TPS includes in its work instructions three elements: (a) Cycle time: The time necessary to produce one piece or unit (b) Standard operations routine: The order of operations in which operators process a product (c) Standard inventory: The minimum amount of work-in-process inventory necessary to process a product [4].

\section{REsUlts AND Discussions}

After applying lean manufacturing tools in present system, the authors monitoring the assembly line for 3 months and 6 months to collect data for studying and analysing the effects of implementing lean manufacturing on different types of wastes as shown in "Fig. 3,", "Fig. 4,", "Fig. 5,", and "Fig. 6," respectively. As shown in Table 5, it was realized that from 6 month after applying lean manufacturing, the total lead time was reduced and closed to real lead time.

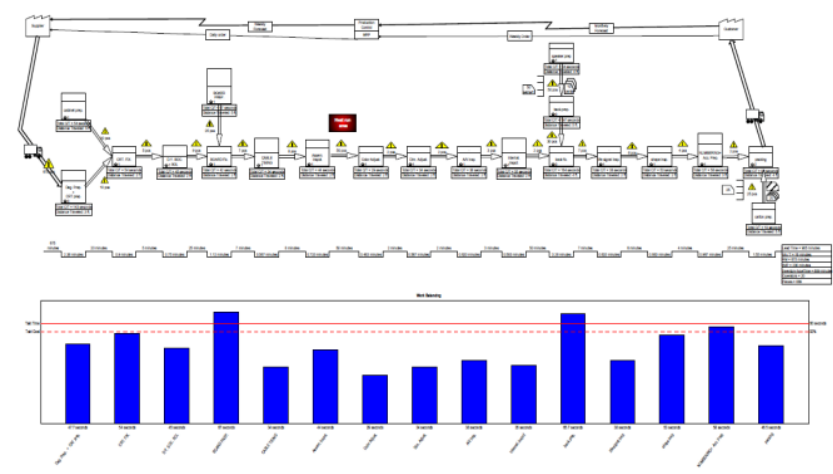




\section{- \\ ELK \\ Asia Pacific Journals}

Fig. 3. Value stream mapping of CRT 14" model after 3 months from applying lean manufacturing

\begin{tabular}{|l|}
\hline Lead Time $=905$ minutes \\
\hline $\mathrm{VA} / \mathrm{T}=16$ minutes \\
\hline $\mathrm{RM}=675$ minutes \\
\hline $\mathrm{WIP}=230$ minutes \\
\hline Inventory typeTime $=889$ minutes \\
\hline Operators $=20$ \\
\hline Pieces $=889$ \\
\hline
\end{tabular}

Fig. 4. Summary box of time line diagram for CRT 14" model after 3 months from applying lean manufacturing

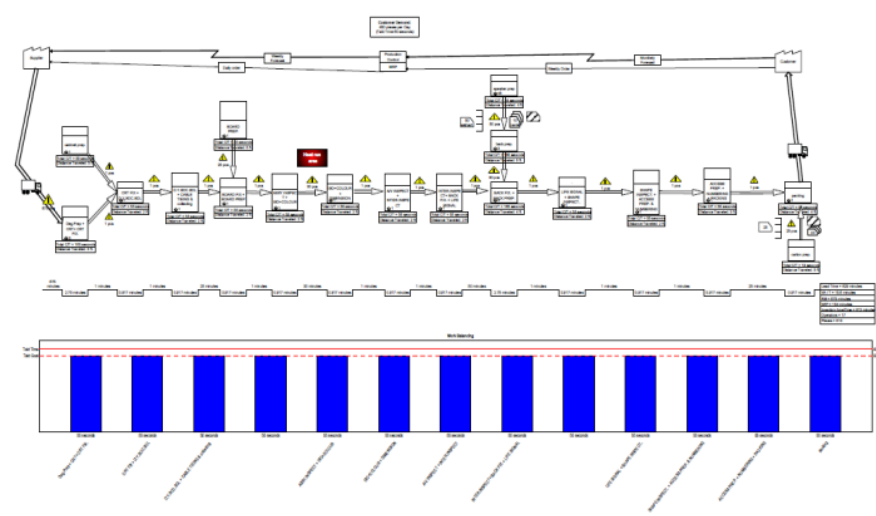

Fig. 5. Value stream mapping of CRT 14" model after 6 months from applying lean manufacturing

\begin{tabular}{|l|}
\hline Lead Time $=829$ minutes \\
\hline $\mathrm{VA} / \mathrm{T}=15.6$ minutes \\
\hline $\mathrm{RM}=675$ minutes \\
\hline $\mathrm{WIP}=154$ minutes \\
\hline Inventory typeTime $=813$ minutes \\
\hline Operators $=17$ \\
\hline Pieces $=813$
\end{tabular}

Fig. 6. Summary box of time line diagram for CRT 14" model after 6 months from applying lean manufacturing

In addition, cycle time, work in progress (WIP), raw materials, inventory, number of operators, number of rejected products were minimized. Value added time and production rate was increased to satisfy the customer's requirements. These results confirm and verify that if the lean manufacturing applied significantly in industrial systems, a lot of benefits will be achieved.

TABLE V. PROCESS ATTRIBUTES BEFORE AND AFTER IMPLEMENTING LEAN MANUFACTURING FOR CRT 14" MODEL

\begin{tabular}{|c|c|c|c|}
\hline & $\begin{array}{c}\text { Before lean } \\
\text { manufacturing }\end{array}$ & $\begin{array}{c}\text { After lean } \\
\text { manufacturing } \\
\text { (3months) }\end{array}$ & $\begin{array}{c}\text { After lean } \\
\text { manufacturing } \\
\text { (6 months) }\end{array}$ \\
\hline $\begin{array}{c}\text { Total Lead } \\
\text { time }\end{array}$ & 1399 Minutes & 905 Mintues & 829 Mintues \\
\hline Total Cycle & 26 Mintues & \multicolumn{2}{|c|}{21 Mintues } \\
\hline Raw Materials & 1000 units / day & \multicolumn{2}{|c|}{675 units / day } \\
\hline $\begin{array}{c}\text { Work in } \\
\text { Progress (WIP) }\end{array}$ & 496 Mintues & 230 Mintues & 154 Mintues \\
\hline Inventory time & 1379 Mintues & 889 Mintues & 813 Mintues \\
\hline $\begin{array}{c}\text { Number of } \\
\text { operators }\end{array}$ & 27 operators & \multicolumn{2}{|c|}{23 operators } \\
\hline $\begin{array}{c}\text { Production } \\
\text { Rate }\end{array}$ & 400 units / day & 425 units / day & 440units / day \\
\hline
\end{tabular}

ELK Asia Pacific Journals - Special Issue ISBN: 978-81-930411-4-7

\begin{tabular}{|c|c|c|c|}
\hline $\begin{array}{c}\text { Number of } \\
\text { Rejected }\end{array}$ & 12 units / day & 8 units / day & 5 units / day \\
\hline
\end{tabular}

\section{CONCLUSIONS AND RECOMMENDATIONS}

After the implementation of lean manufacturing, several benefits were obtained. Different types of manufacturing and time wastes were eliminated. Cycle time, and lead time were decreased by $19 \%$ and $41 \%$ respectively. Value added time was increased while Non value added time was decreased. Raw materials in the production line, work in progress (WIP), inventory, number of operators, and number of rejections were decreased by $33 \%, 69 \%, 41 \%, 15 \%$, and $58 \%$ respectively. Production rate was increased by $18 \%$ to satisfy the customer's needs. Lean concept is not only a set of mutually supporting technique, but is also a global change in organization's culture. Hence it is the most important factor for any quality or productivity improvement. It is recommended to use preventive maintenance to increase the performance of production system and also to avoid unplanned equipment downtime. In addition, Total productive maintenance (TPS) is recommended for implementing in the production system. Implementation of TPM will increase the efficiency of production system as well the useful life of the equipment involved.

\section{Acknowledgement}

Authors are also thankful to the management of Sunny Egypt Company for Electronics Industry which related to UNION AIR GROUP, Egypt.

\section{References}

[1] Gupta, A. and Kundra, T. K. A review of designing machine tool for leanness. Sadhana; Vol. 37, Part 2, pp 241259, 2012.

[2] Muslimen, R., Mohd Yusof, S. and Abidin, A. S. Z. Lean Manufacturing Implementation in Malaysian Automotive Components Manufacturer: a case Study. Proceedings of the World Congress on Engineering Vol. I, 2011.

[3] Rajenthirakumar, D., Mohanram, P. V. and Harikarthik, S. G.Process Cycle Efficiency Improvement through Lean: a case Study. International Journal of Lean Thinking; Vol. 2 (1), 2011.

[4] Nordin, N., Deros, B. M. and Wahab, D. A. A survey on lean manufacturing implementation in Malaysian automotive industry. International Journal of Innovation, Management and Technology; Vol. 1, pp 374-380, 2010.

[5] N. Nordin, B. M. Deros, and D. A. Wahab, "A survey on lean manufacturing implementation in Malaysian automotive industry," International Journal of Innovation, Management and Technology, vol. 1, pp. 374-380, 2010.

[6] Wong, Y. C., Wong, K. Y. and Ali, A. A Study on Lean Manufacturing Implementation in the Malaysian Electrical and Electronics Industry. European Journal of Scientific Research; Vol. 38, PP 521-535, 2009. 
ELK

Asia Pacific Journals
ELK Asia Pacific Journals - Special Issue ISBN: 978-81-930411-4-7 